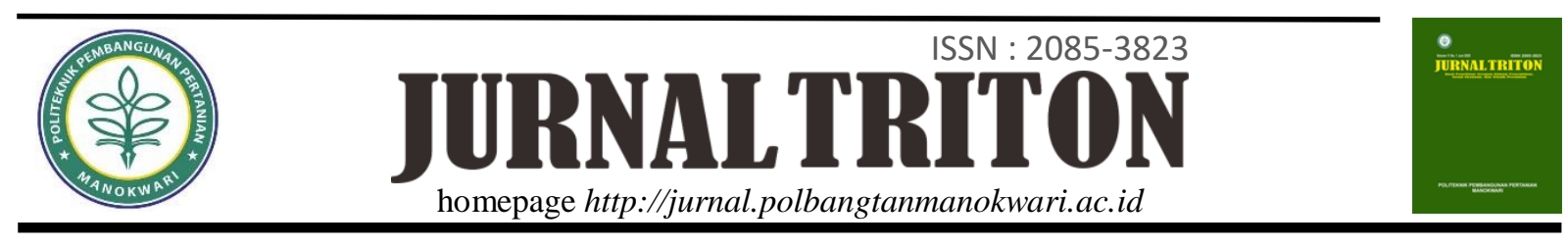

\title{
Mortalitas dan Profil Organ Dalam Ayam Kampung yang diberi Fitobiotik Nanoenkapsulasi Minyak Buah Merah (Pandanus conoideus)
}

\author{
Ni Putu Vidia Tiara Timur ${ }^{1 *}$, Maria Herawati $^{2}$, Bangkit Lutfiaji Syaefullah ${ }^{3}$, Ebit Eko Bachtiar $^{4}$ \\ 1,2,3,4 Prodi Penyuluhan Peternakan dan Kesejahteraan Hewan, Politeknik Pembangunan Pertanian Manokwari
}

\begin{tabular}{l}
\multicolumn{1}{c}{ ARTIKEL INFO } \\
\hline Sejarah artikel \\
Diterima 03/06/2020 \\
Diterima dalam bentuk revisi $18 / 06 / 2020$ \\
Diterima dan disetujui 25/06/2020 \\
Tersedia online 30/06/2020 \\
\hline Kata kunci : \\
Ayam kampung \\
Minyak buah merah \\
Mortalitas \\
Nanoenkapsulasi \\
Profil organ dalam \\
\hline
\end{tabular}

\begin{abstract}
ABSTRAK
Buah merah adalah salah satu tanaman obat asli Indonesia yang berasal dari Papua dan dipercaya dapat mengobati berbagai macam penyakit. Minyak buah merah diolah dan digunakan sebagai obat herbal dan fitobiotik bagi ternak. Pemberian fitobiotik ini bertujuan untuk mengoptimalkan mekanisme kerja dari masing-masing bioaktif dalam buah merah sebagai antibakteri untuk menggantikan antibiotik yang digunakan sebagai feed additive pada pakan ternak. Objek penelitian ini adalah ayam kampung yang diberikan minyak buah merah via air minum. Penelitian ini dilaksanakan di Politeknik Pembangunan Pertanian Manokwari selama dua bulan pada bulan Oktober sampai November 2019. Tujuan dari penelitian ini adalah untuk mengetahui pengaruh penambahan nanoenkapsulasi minyak buah merah pada air minum dengan beberapa perlakuan (P0:kontrol; P1: ekstrak minyak buah merah 2,5\%; P2: nanoenkapsulasi minyak buah merah 2,5\%; P3: nanoenkapsulasi minyak buah merah $5 \%$ dan P4: nanoenkapsulasi minyak buah merah $10 \%$ ) terhadap mortalitas dan profil organ dalam dari ayam kampung. Setiap hari dilakukan pengamatan terhadap kematian (mortalitas) ayam kampung dan pada hari ke 56 ayam dipanen kemudian dilakukan pengamatan dan pengukuran pada organ dalam seperti organ hati, jantung, dan usus halus. Data penelitian ini dianalisis menggunakan metode analisis diskriptif. Hasil penelitian menunjukkan bahwa penambahan nanoenkapsulasi minyak buah merah sebagai additive tidak berpengaruh nyata $(\mathrm{F}<0,05)$ terhadap mortalitas ayam kampung, berat pada organ hati, jantung, dan usus halus. Sehingga dapat disimpulkan bahwa penambahan nanoenkapsulasi minyak buah merah sebagai additive tidak menurunkan tingkat mortalitas ayam kampung, dan tidak menunjukkan perubahan profil organ dalam.
\end{abstract}

(C) 2020 Politeknik Pembangunan Pertanian Manokwari 


\section{ABSTRACT}

Red fruit is one of the original Indonesian medicinal plants that comes from Papua and is believed to be able to treat various diseases. Red fruit oil is processed and used as herbal medicine and phytobiotics for livestock. The giving of phytobiotics aims to optimize the mechanism action of each bioactive in red fruit as an antibacterial to replace the antibiotics used as feed additives in animal feed. The object of this study is local chickens given red fruit oil via water intake. The research was conducted at the Manokwari Agricultural Development Polytechnic for two months in October to November 2019. The purpose of this study was to determine the effect of adding red fruit oil nanoencapsulation via water intake with several treatments (P0: control; P1: red fruit oil extract 2.5\%; P2: nanoencapsulation of red fruit oil $2.5 \%$;

\section{PENDAHULUAN}

Industri peternakan melakukan pemberian antibiotika sebagai imbuhan pakan (feed additive) dengan tujuan memicu pertumbuhan yang cepat (growth promotor), meningkatkan produksi, dan meningkatkan efisiensi penggunaan pakan (Bahri et al., 2005).

Namun saat ini di Indonesia penggunaan antibiotika untuk ternak yang produknya dikonsumsi manusia tersebut dilarang. Hal ini dikarenakan penggunaan antibiotika pada ternak yang dikonsumsi manusia dapat meninggalkan residu pada produk peternakan (Gaskins et al., 2006). Berdasarkan berbagai penelitian yang telah dilakukan, ditemukan bahwa alternatif lain dari antibiotik yang aman adalah menggunakan hasil tanaman atau dikenal dengan fitobiotik (Grashorn, 2010). Fitobiotik pada unggas dapat meningkatkan pertumbuhan dan efisiensi pakan, memperbaiki histomorfologi usus, serta dapat berfungsi sebagai antimikroba sehingga dapat meningkatkan daya tahan tubuh unggas (Hosseini et al., 2016). Salah satu fitobiotik
P3: nanoencapsulation of red fruit oil 5\% and P4: nanoencapsulation of red fruit oil 10\%) on mortality and internal organ profile of local chickens. Every day observations of mortality of native chickens are carried out and on day 56 chickens are harvested then observations and measurements on internal organs such as the liver, heart and small intestine. The data of this study were analyzed using descriptive analysis method. The results showed that the addition of nanoencapsulation of red fruit oil as an additive had no significant effect $(F<0.05)$ on mortality of local chickens, weight in the liver, heart, and small intestine. So it can be concluded that the addition of nanoencapsulation of red fruit oil as an additive does not reduce the mortality rate of local chickens, and does not show changes in the profile of internal organs.

yang dapat dimanfaatkan sebagai growth promotor alami adalah senyawa metabolit sekunder dari buah merah.

Buah merah adalah salah satu tanaman obat asli Indonesia yang berasal dari Papua dan dipercaya dapat mengobati berbagai macam penyakit. Zat aktif yang merupakan senyawa metabolit yang terkandung dalam buah merah diantaranya adalah tokoferol (vitamin E), alfatokoferol dan betakaroten berfungsi sebagai antioksidan yang mampu menangkal radikal bebas dan meningkatkan kekebalan tubuh (Budi and Paimin, 2005).

Ayam kampung bagi masyarakat Papua merupakan salah satu ternak yang umum untuk dipelihara. Ayam kampung merupakan salah satu komoditas ternak penghasil daging yang sangat digemari oleh masyarakat. Hal tersebut dikarenakan ayam kampung mempunyai cita rasa daging yang berbeda dan kemampuan beradaptasi yang baik terhadap kondisi lingkungan (Mubarak et al., 2018). Sukmawati et al. (2015) menyatakan bahwa daging ayam kampung mempunyai rasa yang gurih dan enak. 
Keunggulan - keunggulan tersebut, perlu didukung agar dapat menghasilkan produktivitas yang tinggi. Peningkatan produktivitas dapat diupayakan dengan cara memberikan pakan yang berkualitas dan additive.

Nanoenkapsulasi senyawa bioaktif dari minyak buah merah dengan metode gelasi ionik kitosan dan STPP (Sodium Tripolyphospate) diharapkan dapat mengoptimalkan mekanisme kerja dari masing-masing bioaktif sebagai antibakteri untuk menggantikan antibiotik yang digunakan sebagai feed additive. Penambahan fitobiotik ini diharapkan mampu menurunkan angka mortalitas dan meningkatkan fungsi organ dari ayam kampung, sehingga diharapkan dapat memaksimalkan produktivitas ayam kampung.

Dengan demikian, penelitian ini bertujuan untuk mengetahui pengaruh pemberian nanoenkapsulai minyak buah merah lewat air minum terhadap mortalitas dan profil organ dalam pada ayam kampung.

\section{METODE}

Bahan yang digunakan dalam penelitian ini adalah minyak buah merah (Pandanus conoideus), ayam kampung betina 100 ekor, kitosan, Sodium Tripolyphosphate (STPP), asam asetat, air, dan pakan dari PT. East Hope.

Alat yang digunakan dalam penelitian ini adalah pisau, talenan, beaker glass, waterbath, timbangan analitik, meteran, label, termohighrometer, kamera, kandang dan perlengkapannya.

\section{Tahapan penelitian}

\section{Ekstraksi minyak buah merah}

Minyak buah merah adalah produk utama dari proses ekstraksi buah merah. Menurut Budi dan Paimin (2005), proses ekstraksi buah merah adalah buah merah matang dipisahkan dari empulurnya (bagian kayu di tengah buah) kemudian dipotong-potong dan dicuci sampai bersih. Daging buah dikukus di atas api sedang selama 1-2 jam, setelah itu dipisahkan dari biji buah dengan cara dikucek dan diperas. Air ditambahkan hingga ketinggian $5 \mathrm{~cm}$ di atas permukaan bahan dan diperoleh sari buah merah yang menyerupai santan, kemudian dimasak kembali dengan api sedang selama 5-6 jam sambil diaduk sampai muncul minyak berwarna kehitaman di permukaan bahan. Setelah didiamkan selama satu hari, akan terbentuk tiga lapisan, yaitu air di lapisan bawah, ampas di lapisan tengah dan minyak di lapisan atas.

\section{Pembuatan nanoenkapsulasi}

Proses nanoenkapsulasi menggunakan metode gelasi ionik dengan mencampurkan $2 \%$ ekstrak minyak buah merah (hasil ekstrak buah merah dengan $96 \%$ etanol): 0,625\% kitosan (kitosan yang telah dilarutkan dalam 2,50\% asam asetat, diaduk dengan menggunakan magnetic stirrer selama 30 menit): 0,75\% STPP (yaitu $0,75 \%$ STPP yang telah dilarutkan dengan aquades dan diaduk menggunakan magnetic stirrer selama 30 menit) (Sundari, 2014. Perbandingan larutan nanoenkapsulasi sebagai fitobiotik yaitu minyak buah merah, kitosan dan STPP (0,50:1,00:0,02) (Herawati et al., 2019). 


\section{Pemeliharaan ayam kampung}

DOC ayam kampung sebanyak 100 ekor dipelihara selama 56 hari di kandang panggung. Setiap hari dilakukan pemeriksaan terhadap kematian (mortalitas) ayam kampung dan pada hari ke 56 ayam dipanen kemudian diukur berat masing-masing organ dalam.

\section{Analisis data}

Metode penelitian ini adalah metode deskriptif dengan 5 level pemberian nanoenkapsulasi dan 4 ulangan, masing-masing ulangan terdiri dari 5 ekor ayam. Level pemberian nanoenkapsulasi yang diberikan adalah: negatif)

$\mathrm{P} 1=$ air minum $+2,5 \%$ ekstrak minyak buah merah

P2 = air minum $+2,5 \%$ nanoenkapsulasi bioaktif minyak buah merah

$\mathrm{P} 3=$ air minum $+5 \%$ nanoenkapsulasi bioaktif minyak buah merah

$\mathrm{P} 4=$ air minum $+10 \%$ nanoenkapsulasi bioaktif minyak buah merah

\section{HASIL DAN PEMBAHASAN}

\section{Mortalitas}

Mortalitas merupakan tingkat kematian ayam pada satu masa periode pemeliharaan. Tingkat persentase kematian atau mortalitas pada penelitian ini dapat dilihat pada Tabel 1 .

Tabel 1. Mortalitas (\%)

\begin{tabular}{rrrrcrcc}
\hline & \multicolumn{4}{c}{ Ulangan } & \multirow{2}{*}{ x } & Sd & $\begin{array}{c}\text { Persentase } \\
(\%)\end{array}$ \\
\cline { 2 - 5 } & \multicolumn{1}{c}{2} & \multicolumn{1}{c}{3} & 4 & & & 7 \\
P0 & 60 & 20 & 20 & 40 & 35 & $\pm 19,15$ & 6 \\
P1 & 20 & 20 & 40 & 40 & 30 & $\pm 11,54$ & 6 \\
P2 & 0 & 0 & 20 & 20 & 10 & $\pm 11,54$ & 2 \\
P3 & 0 & 0 & 0 & 20 & 5 & \pm 10 & 1 \\
P4 & 0 & 20 & 20 & 60 & 25 & $\pm 25,16$ & 5 \\
\hline
\end{tabular}

Berdasarkan hasil analisis data ditunjukkan bahwa penambahan nanoenkapsulasi minyak buah merah sebagai additive tidak berpengaruh nyata $(\mathrm{F}<0,05)$ terhadap persentase mortalitas. Ayam kampung memiliki keunggulan antara lain pertumbuhannya yang cepat, angka kematian yang rendah (sekitar 5 persen) dan mudah beradaptasi dengan lingkungan (Sofjan, 2012). Pada penelitian ini mortalitas ayam secara keseluruhan adalah 21\% (21/100). Angka mortalitas selama pemeliharaan pada perlakuan P0 7 ekor (7\%), P1 6 ekor (6\%), P2 2 ekor (2\%), P3 1 ekor (1\%), dan P4 5 ekor (5\%).

Hasil penelitian ini mengindikasikan bahwa pemberian minyak buah merah dalam air minum memberikan pengaruh positif terhadap penurunan mortalitas ayam kampung. Kematian terendah pada perlakuan P3 (air minum $+5 \%$ nanoenkapsulasi bioaktif minyak buah merah) dimana kematian hanya ditemukan 1 ekor (1\%) dalam kelompoknya. Pemberian minyak buah merah dalam air minum dapat meningkatkan daya tahan tubuh ayam sehingga ayam akan menjadi tahan terhadap penyakit dan angka mortalitas yang diperoleh masih rendah $(1 / 20)$ atau $5 \%$ dari total kematian. Kematian biasanya terjadi pada periode awal (starter), sedangkan pada periode finisher jarang terjadi (Risa et al., 2014). Tingkat mortalitas yang tercatat pada penelitian ini memang relatif tinggi. Pada periode stater kematian disebabkan oleh faktor lingkungan. Faktor-faktor tersebut diantaranya adalah faktor suhu/cuaca pada ayam ketika cuaca hujan dan sumber listrik yang tidak tersedia dengan cukup (seringnya listrik padam) dalam waktu yang lama. Pada 
minggu kedua, hujan terjadi secara terus menerus dan listrik padam menyebabkan ayam kedinginan dan sangat mudah terserang penyakit. Ayam terlihat lesu dan nafsu makannya berkurang kemudian mati. Ketika ayam mulai dewasa kematian lebih didominasi oleh tingkah laku agresif dari satu atau dua ekor ayam dalam kelompok yang memicu terjadinya pematukan terhadap beberapa ekor ayam dalam kelompok ulangannya.

Tabel 2. Berat Hati (\%)

\section{Profil Organ Dalam}

\section{Hati}

Hati merupakan kelenjar terbesar dalam tubuh dan merupakan organ ekskresi yang membantu peran ginjal dalam tubuh. Hati berfungsi sebagai tempat menyimpan cadangan energi berupa glikogen yang diperlukan dalam proses glikolisis (Blakely \& Bade, 1992). Berat organ hati pada ayam kampung dapat dilihat pada Tabel 2.

\begin{tabular}{|c|c|c|c|c|c|c|}
\hline & \multicolumn{4}{|c|}{ Ulangan } & \multirow{2}{*}{ Rataan } & \multirow{2}{*}{$\mathrm{Sd}$} \\
\hline & 1 & 2 & 3 & 4 & & \\
\hline P0 & 2,54 & 2,67 & 2,62 & 2,32 & 2,54 & $\pm 0,13$ \\
\hline $\mathrm{P} 1$ & 3,02 & 3,93 & 4,44 & 3,05 & 3,61 & $\pm 0,60$ \\
\hline $\mathrm{P} 2$ & 2,82 & 2,68 & 3,43 & 3,22 & 3,04 & $\pm 0,30$ \\
\hline P3 & 3,21 & 3,52 & 3,2 & 3,09 & 3,26 & $\pm 0,16$ \\
\hline $\mathrm{P} 4$ & 3,02 & 3,51 & 2,94 & 3,06 & 3,13 & $\pm 0,22$ \\
\hline
\end{tabular}

$\begin{array}{rrr}\text { Berdasarkan } & \text { hasil analisis data } \\ \text { menunjukan } & \text { bahwa } & \text { penambahan }\end{array}$
nanoenakpsulasi minyak buah merah sebagai additive tidak berpengaruh nyata $(\mathrm{F}<0,05)$ terhadap berat hati. Hati merupakan kelenjar terbesar dalam tubuh dan merupakan organ ekskresi yang membantu peran ginjal dalam tubuh. Hati berfungsi sebagai tempat menyimpan cadangan energi berupa glikogen yang diperlukan dalam proses glikolisis (Blakely and Bade, 1992). Rataan persentase berat hati yang diperoleh dari hasil penelitian ini berkisar antara 2,54-3,61\% dari berat hidup, nilai tersebut tidak sesuai dengan kisaran yang dilaporkan Putnam (1991) yaitu 1,7-2,8\% dari berat hidup ayam pedaging. Hanya pada perlakuan P0 $(2,54 \%)$ persentase berat hati dalam kisaran normal. Tidak ada standar berat hati ayam kampung yang sudah diteliti. Sehingga standar ini menggunakan standar ayam pedaging. Apabila sesuai dengan standar ayam pedaging, ayam dalam penelitian ini terjangkit FLS (Fatty Liver Syndrome) ditandai dengan adanya akumulasi lemak dalam jumlah besar pada rongga perut dan organ-organ visceral, ukuran hati lebih besar dari ukuran normal, lemak secara ekstrim meluas di permukaan hati dengan ukuran dan warna bervariasi (Rahayu, 2010).

\section{Jantung}

Jantung adalah organ utama dalam sistem peredaran darah, jantung memiliki empat ruang yaitu, atrium kanan, vertikel kanan, atrium kiri, dan vertikel kiri. Jantung merupakan struktur muskular berongga yang bentuknya menyerupai kerucut (Frandson, 1993). Rataan persentase berat jantung yang diperoleh dari hasil penelitian ini berkisar antara 0,49-0,63\% dari berat hidup. Putnam (1991), menyatakan bahwa persentase berat jantung ayam pedaging 
sekitar $0,42-0,7 \%$ dari berat hidup. Rataan persentase ini tidak terlalu jauh berbeda dengan rataan pada ayam pedaging dan masih dalam rentang normal. Berdasarkan hasil analisis data Tabel 3. Berat Jantung (\%) menunjukan

bahwa

penambahan nanoenakpsulasi minyak buah merah sebagai additive tidak berpengaruh nyata $(\mathrm{F}<0,05)$ terhadap berat jantung.

\begin{tabular}{|c|c|c|c|c|c|c|}
\hline & \multicolumn{4}{|c|}{ Ulangan } & \multirow{2}{*}{ Rataan } & \multirow{2}{*}{$\mathrm{sd}$} \\
\hline & 1 & 2 & 3 & 4 & & \\
\hline P0 & 0,43 & 0,47 & 0,51 & 0,56 & 0,49 & $\pm 0,05$ \\
\hline P1 & 0,69 & 0,61 & 0,63 & 0,62 & 0,63 & $\pm 0,03$ \\
\hline $\mathrm{P} 2$ & 0,48 & 0,55 & 0,73 & 0,63 & 0,59 & $\pm 0,10$ \\
\hline P3 & 0,52 & 0,68 & 0,57 & 0,62 & 0,59 & $\pm 0,07$ \\
\hline P4 & 0,52 & 0,61 & 0,6 & 0,81 & 0,63 & $\pm 0,12$ \\
\hline
\end{tabular}

\section{Gizzard}

Gizzard adalah muscular stomach (perut otot) atau empedal. Lokasinya berada diantara ventriculus dan bagian atas usus halus. Fungsi utama empedal adalah melumatkan pakan dan mencampur dengan air menjadi pasta yang dinamakan chymne. Ukuran dan kekuatan empedal dipengaruhi oleh kebiasaan makan ayam tersebut. Ayam yang dipelihara empedalnya lebih kuat dari pada ayam yang dikurung (Yuwanta, 2004). Gizzard adalah $1,6 \%-2,3 \%$ dari bobot hidup (Sturkie, 2000). Pada penelitan ini rata-rata berat gizzard adalah $1,87 \%$ - 2,45\%. Pada kelompok ayam yang diberi perlakuan (P1,P2,P3,P4) berat gizzard berada pada rentang normal, sedangkan pada pada ayam yang tidak diberi perlakuan dengan Tabel 4. Berat Gizzard (\%) nanoenkapsulasi minyak buah merah $(\mathrm{P} 0)$ berat gizzard melebihi batas normal.

Weiss dan Scott (1979) dalam Rosyani (2013) juga menyatakan, bahwa serat yang tinggi dalam pakan akan memperbesar ukuran gizzard karena organ tersebut dipacu untuk lebih banyak bekerja secara fisiologis dalam memproses pencernaan serat, baik secara mekanik maupun enzimatis. Menurut Rosyani (2013), ukuran gizzard mudah berubah bergantung pada jenis makanan yang biasa dimakan oleh unggas tersebut. Ukuran gizzard yang mengecil kemungkinan disebabkan oleh penambahan minyak buah merah sehingga mempermudah dalam proses pencernaan pakan baik secara mekanik dan enzimatis.

\begin{tabular}{|c|c|c|c|c|c|c|}
\hline & \multicolumn{4}{|c|}{ Ulangan } & \multirow{2}{*}{ Rataan } & \multirow{2}{*}{$\mathrm{Sd}$} \\
\hline & 1 & 2 & 3 & 4 & & \\
\hline P0 & 2,37 & 2,19 & 2,82 & 2,44 & 2,45 & $\pm 0,26$ \\
\hline $\mathrm{P} 1$ & 1,98 & 2,21 & 2,09 & 1,85 & 2,06 & $\pm 0,19$ \\
\hline $\mathrm{P} 2$ & 1,95 & 2,06 & 2,18 & 1,7 & 1,96 & $\pm 0,20$ \\
\hline P3 & 2,24 & 2,39 & 1,92 & 1,92 & 2,11 & $\pm 0,23$ \\
\hline P4 & 1,69 & 2,1 & 1,8 & 1,89 & 1,87 & $\pm 0,17$ \\
\hline
\end{tabular}




\section{Usus Halus}

Usus halus merupakan organ yang relatif panjang sehingga memungkinkan kontak yang lama antara makanan dan enzim-enzim pencernaan serta antara hasil-hasil pencernaan dan sel-sel absorptif epitel pembatas. Usus halus terdiri atas tiga segmen yaitu, duodenum, jejunum, dan ileum. Berdasarkan penelitian yang telah dilakukan dengan penambahan nanoenkapsulasi minyak buah merah rata-rata berat usus halus $3,51 \%-4,74 \%$ dari berat Tabel 5. Berat Usus Halus (\%) badan. Menurut Yang et al. (2013) menyatakan bahwa peningkatan berat usus kecil sejalan dengan peningkatan asupan nutrisi pada awal kehidupan ayam, kemudian terjadi peningkatan secara progresif baik di daerah penyerapan dan kapasitas mukosa untuk hidrolisis. Berdasarkan hasil analisis data menunjukan bahwa penambahan nanoenakpsulasi minyak buah merah sebagai additive tidak berpengaruh nyata $(\mathrm{F}<0,05)$ terhadap berat usus halus.

\begin{tabular}{|c|c|c|c|c|c|c|}
\hline & \multicolumn{4}{|c|}{ Ulangan } & \multirow{2}{*}{ Rataan } & \multirow{2}{*}{$\mathrm{Sd}$} \\
\hline & 1 & 2 & 3 & 4 & & \\
\hline P0 & 3,72 & 2,53 & 3,33 & 3,47 & 3,51 & $\pm 0,16$ \\
\hline P1 & 3,96 & 6,03 & 5,07 & 3,9 & 4,74 & $\pm 1,01$ \\
\hline P2 & 4,19 & 3,68 & 3,83 & 3,28 & 3,74 & $\pm 0,37$ \\
\hline P3 & 4,22 & 3,64 & 3,34 & 3,92 & 3,78 & $\pm 0,37$ \\
\hline P4 & 3,67 & 4,72 & 3,6 & 3,58 & 3,89 & $\pm 0,55$ \\
\hline
\end{tabular}

\section{KESIMPULAN DAN SARAN}

Penambahan nanoenakpsulasi minyak buah merah sebagai additive tidak menurunkan tingkat mortalitas ayam kampung, dan tidak menunjukkan perubahan profil organ dalam yang berbeda seperti pada organ hati, jantung, dan usus halus.

\section{UCAPAN TERIMAKASIH}

Terimakasih kepada Kementerian Pertanian RI dan Politeknik Pembangunan Pertanian Manokwari yang telah memberikan bantuan dana dan dukungannya serta para mahasiswa yang telah membantu penelitian ini hingga akhir.

\section{DAFTAR PUSTAKA}

Bahri, S., E. Masbulan, \& A. Kusumaningsih. (2005). Proses Praproduksi sebagai Faktor Penting dalam Menghasilkan
Produk Ternak yang Aman untuk Manusia. Jurnal Litbang Pertanian 24(1).

Blakely, J. \& D. H. Bade. (1992). Pengantar Ilmu Peternakan. Penerjemah: B. Srigandono. Cet. ke-2. Gadjah Mada University Press. Yogyakarta.

Budi, I.M., \& Paimin, F.R. (2005). Buah Merah. Jakarta: Penebar Swadaya.

Frandson, R.D. (1993). Anatomi dan Fisiologi Ternak. Gadjah Mada University Press. Yogyakarta

Gaskins, H.R., C.T. Collier, \& D.B. Anderson. (2006). Antibiotics as Growth Promotants: Mode of Action. Animal Biotechnology. 13: $29-42$.

Grashorn, M., (2010). Use of Phytobiotics in Broiler Nutrition - An Alternative to Infeed Antibiotics. Journal of Animal and Feed Sciences. 19: 319-328.

Herawati, M., Timur, N. P. V. T., Bachtiar, E. 
E., Maulana, F., \& Syaefullah, B. L. (2019). INCOME OVER FEED COST PADA AYAM KAMPUNG YANG DIBERI NANOENKAPSULASI MINYAK BUAH MERAH (Pandanus conoideus) VIA WATER INTAKE. JURNAL TRITON: PERTANIAN, 10(2), 54-61.

Hosseini, S., M. Chamani, A. Seidavi, A.A. Sadeghi, \& Z. Pirsareai. (2016). Effect on Feeding Thymolina Powder in The Carcass Characteristics and Morphology of Small Intestine of Ross 308 Broiler Chickens. Jurnal Veteriner. 17: 615621.

Mubarak, P. R., L. D. Mahfudz, \& D. Sunarti. (2018). Pengaruh pemberian probiotik pada level protein pakan berbeda terhadap perlemakan ayam kampung. Jurnal Sain Peternakan Indonesia. 13(4) : 357- 36 .

Putnam, P. A. (1991). Handbook of Animal Science. Academic Press. San Diego.

Rahayu, D.I. (2010). Sindrom Hati Berlemak pada Ayam Petelur. http://imbang.staff.umm.ac.id/?p=147. 2010. Diakses pada tanggal 12 Januari 2020. Rosyani

Rosyani, S. (2013). Pemberian Pakan Konsentrat Mengandung Tepung Inti Sawit yang Ditambahkan Pollard atau Dedak dan Pengaruhnya terhadap Persentase Organ Dalam Ayam Broiler. Skripsi. Institut Pertanian Bogor. Bogor

Sofjan I. (2012). Ayam Kampung Unggul Balitnak. Badan Penelitian dan Pengembangan Pertanian. Jakarta

Sukmawati, N. M.S., I.P. Sampurna, M. Wirapartha, N.W. Siti, \& I.N. Ardika. (2015). Penampilan dan komposisi fisik karkas ayam kampung yang diberi jus daun pepaya terfermentasi dalam ransum komersial. Majalah Ilmiah Peternakan. $18(2)$ : 39-43.
Sundari, Zuprizal, \& R. Martien. (2014). The Effect Nanocapsule of Turmeric Extracts in Rations on Nutrient Digestibility of Broiler Chickens. Animal Production. 16: 107-113.

Yang HM, Wang W, Wang ZY, Wang J, Cao YJ, \& Chen YH. (2013). Comparative study of intestine length, weight and digestibility on different body weight chickens. African Journal of Biotechnology. 12 (23): 5097-5100.

Yuwanta, T. (2000). Beberapa Metode Praktis Penetasan Telur. Fakultas Peternakan. Universitas Gadjah Mada. Yogyakarta.

Risa, E., Rahmawati Semaun \&Intan Dwi Novita. (2014). Evaluasi Penurunan Angka Mortalitas dan Morbiditas Ayam Pedaging yang Mendapatkan Penambahan Tepung Lempuyang (Zingiber aromaticum val) dalam Ransum. Jurnal Galung Tropika. 3(3) :192-200. 